\title{
A conjugated mTOR/MEK bifunctional inhibitor as potential polypharmacological anticancer agent: the prototype compound discovery
}

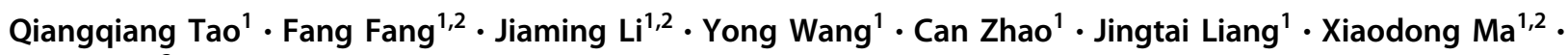 \\ Hao Wang ${ }^{3}$
}

Received: 17 November 2019 / Accepted: 6 January 2020 / Published online: 13 January 2020

(c) Springer Science+Business Media, LLC, part of Springer Nature 2020

\begin{abstract}
mTOR/MEK bifunctional inhibitors have the potential to surmount the drug resistance aroused from cross talk between PI3K/Akt/mTOR (PAM) and Ras/MEK/ERK pathways. Herein, we report the discovery of a conjugated dual-targeted molecule, compound 13, as the prototype mTOR/MEK bifunctional inhibitor. It exhibited moderately high inhibitory activity against mTOR and MEK1 with $\mathrm{IC}_{50}$ values of $0.19 \mu \mathrm{M}$ and $0.98 \mu \mathrm{M}$, respectively. In particular, it displayed attractive antiproliferative activity against both $\mathrm{A} 549\left(\mathrm{GI}_{50}=4.66 \mu \mathrm{M}\right)$ and $\mathrm{HCT} 116\left(\mathrm{GI}_{50}=5.47 \mu \mathrm{M}\right)$ cell lines. To our knowledge, it has been the first example of a conjugated mTOR/MEK bifunctional inhibitor. In addition, from this proof-ofprinciple study, it has become evident that the single-agent dual inhibition of mTOR and MEK can be fulfilled via covalently attaching mTOR kinase inhibitor to an allosteric MEK inhibitor.
\end{abstract}

Keywords Drug resistance $\cdot$ Cross talk $\cdot$ mTOR/MEK bifunctional inhibitor $\cdot$ mTOR kinase inhibitor $\cdot$ Allosteric MEK inhibitor

\section{Introduction}

As a major concern in the research community, drug resistance against single pathway inhibition has posed a considerable obstacle to cancer treatment (Ma et al. 2018). Particularly, a plethora of clinically investigated kinase

Supplementary information The online version of this article (https:// doi.org/10.1007/s00044-020-02502-x) contains supplementary material, which is available to authorized users.

Xiaodong Ma

o-omaxiaodong@163.com

$\triangle$ Hao Wang

wanghao986118@163.com

1 School of Pharmacy, Anhui University of Chinese Medicine, Hefei 230012, China

2 Department of Medicinal Chemistry, Anhui Academy of Chinese Medicine, Hefei 230012, China

3 Department of Clinical Laboratory, The First Affiliated Hospital of University of Science and Technology of China, Hefei 230001, China inhibitors (KIs) suffer from insufficient therapeutic response attributed to the redundancy in cancer-related survival pathways, thereby hindering their further progress. The PI3K/Akt/ mTOR (PAM) pathway inhibitors fit into the scenario, where monotherapy upregulates compensatory cellular signaling (Heavey et al. 2016). Ras/MEK/ERK cascade, another pivotal intracellular survival signaling (Chappell et al. 2011; Tsai and Nussinov 2013), is involved in molecular reciprocity with PAM pathway. The cross talk and feedback loop between them exist due to interaction at various signaling nodes, exemplified by mTOR (Holt et al. 2012; Zhang et al. 2011; Chow et al. 2017; Eser et al. 2013; Yang et al. 2012). Besides, the concurrent deregulation of both pathways contributes to the etiology of a variety of malignancies (Garcia-Garcia et al. 2015). To conquer the bypass mechanism and achieve synergism, drug cocktails simultaneously modulating PAM and Ras/MEK/ERK pathways have been investigated throughout recent years (Cante-Barrett et al. 2016; Pitts et al. 2014; Mohan et al. 2015; Park et al. 2015). However, owing to the limitations of drug cocktails, including the combined off-target effects, complicated pharmacokinetics and therapeutic regimen, as well as potential drug-drug interactions, the exploration of polypharmacological agents ablating 
Fig. 1 MXD-42 (1) and its binding mode with mTOR

Fig. 2 RO-5126766 (2), its binding mode with MEK1 (Van Dort et al. 2015), and the generation of MEK-binding fragment
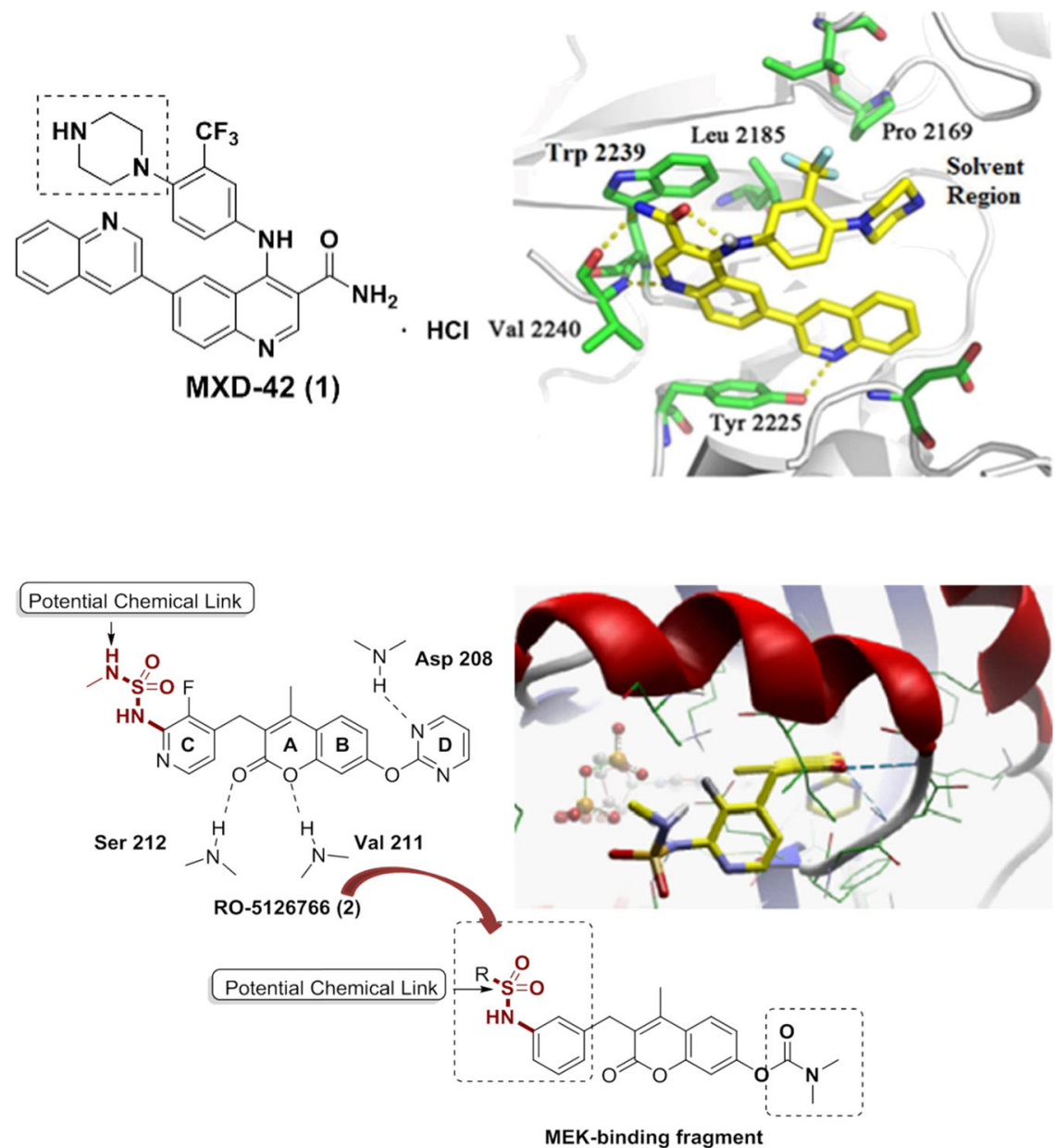

multiple disease-related pathways has been given increasing importance (Ma et al. 2018).

As a well-established therapeutic target along PAM cascade, mTOR has been concomitantly inhibited with MEK in drug combinations for improving the therapeutic outcome. For instance, combination of AZD-8055 (ATPcompetitive mTOR inhibitor) and selumetinib (MEK inhibitor) culminated in the reciprocal pathway inhibition and increased apoptosis in tumor tissue from mouse xenograft models of non-small cell lung cancer and colorectal carcinoma (Holt et al. 2012). In addition, the synergism between them was also observed in treating rhabdomyosarcoma (Renshaw et al. 2013). Nonetheless, to our knowledge, no mTOR/MEK bifunctional inhibitors have been disclosed so far. Bifunctional inhibitors of this kind and the recently reported PI3K/MEK dual inhibitors (Van Dort et al. 2017) have the potential to provide novel remedies for cancer treatment.

During our previous work in search for mTOR KI, a promising quinoline derivative $\operatorname{MXD}-42$ (1, Fig. 1) was identified with remarkable inhibitory activity against mTOR, as well as potent antiproliferative activity against tumor cell lines (Ma et al. 2015). According to the molecular docking analysis, its piperazine moiety oriented toward the solvent-exposed region. This was consistent with the structure-activity relationships (SARs) of these quinoline derivatives, which illustrated appropriate derivatization at the piperazine did not dramatically alter the enzymatic activity. In view of these, the piperazine of $\mathbf{1}$ may serve as a synthetic handle for attaining conjugated mTOR/MEK bifunctional inhibitors via being attached to MEK inhibitor through a chemical linkage. The binding mode of RO5126766 (2, Fig. 2), an allosteric MEK inhibitor under clinical evaluation (phase I, https://clinicaltrials.gov/), with MEK1 demonstrated its pyridine moiety extended out towards the solvent-exposed region with the terminal nitrogen of the sulphonylurea conferring a vector for structural derivatization (Lito et al. 2014). Furthermore, SARs study of 2 showed replacement of the pyrimidin-2yloxy group with a dimethylaminocarbamate moiety enhanced MEK affinity (Iikura et al. 2011; Van Dort et al. 2015). Although replacing the 3-fluoropyridine-2aminosulfonamide group with a simpler 3-(sulfonamido) phenyl moiety slightly lowered the activity, it simplified the 
covalent linking to the mTOR-binding fragment (Fig. 2). Based on the considerations stated above, we have recently conducted a proof-of-principle study to validate the feasibility of achieving mTOR/MEK dual inhibition via covalently linking mTOR KI to an allosteric MEK inhibitor. Herein, we communicate our discovery of a conjugated mTOR/MEK1 dual-targeted inhibitor from 1 and 2 (Fig. 3).

\section{Results and discussion}

\section{Chemistry}

The synthesis of conjugated compounds $\mathbf{1 1}$ and $\mathbf{1 3}$ was displayed in Scheme 1. Ethyl acetoacetate 3, as the starting material, firstly experienced benzylation upon the treatment

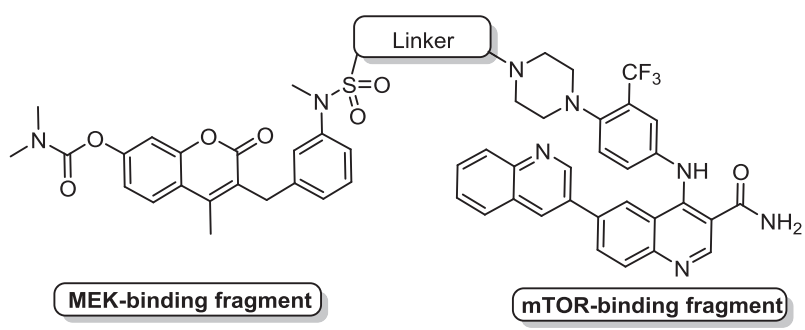

Fig. 3 The design rationale of target conjugated mTOR/MEK bifunctional inhibitors of 1-(bromomethyl)-3-nitrobenzene $\mathbf{4}$ in the presence of $\mathrm{NaH}$. The resultant intermediate $\mathbf{5}$ was then condensed with resorcinol to give the coumarin derivative 6. $N, N$-dimethyl carbamylation of its hydroxyl functionality and the following reduction of nitro group provided the aniline derivative 8. Afterwards, it was condensed with 3chloropropane-1-sulfonyl chloride to afford the sulfonamide 9. Subsequent $N$-methylation at the sulfonamide moiety of $\mathbf{9}$ furnished $\mathbf{1 0}$ as the key intermediate. It was subjected to nucleophilic substitution with $\mathbf{1}$ to provide the conjugated compound 11. Condensation of 1 with 4-((tertbutoxycarbonyl)amino)butanoic acid, and the subsequent removal of the Boc-protecting group generated the primary amine, which was used directly for the next step without further purification. Ultimately, the newly afforded Bocdeprotected product underwent nucleophilic substitution with $\mathbf{1 0}$ to provide the conjugated compound $\mathbf{1 3}$.

\section{Reagents and conditions}

(a) $\mathrm{NaH}(60 \%)$, tetrahydrofuran (THF), $0{ }^{\circ} \mathrm{C}$ to $\mathrm{rt}, \mathrm{N}_{2}$; (b) resorcinol, $\mathrm{H}_{2} \mathrm{SO}_{4}$ (conc.), $0{ }^{\circ} \mathrm{C}$ to $\mathrm{rt}$; (c) $\mathrm{K}_{2} \mathrm{CO}_{3}$, dimethylcarbamyl chloride, $\mathrm{N}, \mathrm{N}$-dimethylformamide (DMF), $40^{\circ} \mathrm{C}$; (d) $\mathrm{SnCl}_{2}$ (dihydrate), EtOAc (EA), $50{ }^{\circ} \mathrm{C}, \mathrm{N}_{2}$; (e) 3chloropropane-1-sulfonyl chloride, pyridine, rt; (f) MeI, $\mathrm{Cs}_{2} \mathrm{CO}_{3}$, DMF, rt; (g) 1, $\mathrm{K}_{2} \mathrm{CO}_{3}$, KI, triethylamine (TEA), $\mathrm{CH}_{3} \mathrm{CN}$, reflux, $\mathrm{N}_{2}$; (h) 4-(tert-butoxycarbonyl)amino)
Scheme 1 Synthetic route for target compounds<smiles>CCCOC(=O)C(Cc1cccc([N+](=O)[O-])c1)C(=O)OCC[B]C(C)CBr</smiles><smiles>Cc1c(Cc2cccc(N)c2)c(=O)oc2cc(OC(=O)N(C)C)ccc12</smiles><smiles>Cc1c(Cc2cccc(NS(=O)(=O)[SiH3])c2)c(=O)oc2cc(OC(=O)N(C)CC(C)(Cl)Cl)ccc12</smiles><smiles>CC(C)(C)NC(=O)N1CCN(c2ccc(Nc3c(C(N)=O)cnc4ccc(-c5cnc6ccccc6c5)cc34)cc2C(F)(F)F)CC1</smiles> 
Table 1 The enzymatic and antiproliferative activities of target compounds

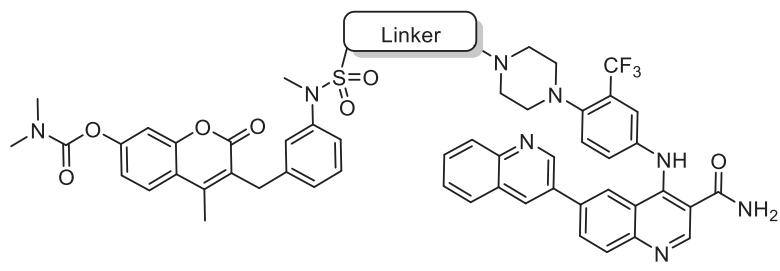

\begin{tabular}{|c|c|c|c|c|c|}
\hline Cpd. & Linker & $\begin{array}{c}\text { mTOR } \\
\left(\mathrm{IC}_{50}, \boldsymbol{\mu M}\right)\end{array}$ & $\begin{array}{c}\text { MEK1 } \\
\left(\mathrm{IC}_{50}, \boldsymbol{\mu M}\right)\end{array}$ & $\begin{array}{c}\mathrm{A549} \\
\left(\mathrm{GI}_{50}, \mu \mathrm{M}\right)\end{array}$ & $\begin{array}{c}\text { HCT116 } \\
\left(G_{50}, \mu M\right)\end{array}$ \\
\hline 11 & & 2.36 & 4.97 & $\mathrm{a}$ & $\mathrm{a}$ \\
\hline 13 & & 0.19 & 0.98 & 4.66 & 5.47 \\
\hline MXD-42 & --- & 0.014 & $>10$ & 2.80 & 5.06 \\
\hline RO-5126766 & --- & $>10$ & 0.16 & 5.07 & 3.23 \\
\hline
\end{tabular}

${ }^{a}$ Unidentified.

butanoic acid, 1-(3-dimethylaminopropyl)-3-ethylcarbodiimide hydrochloride (EDCI), 1-hydroxybenzotriazole (HOBT), TEA, dichloromethane (DCM), rt; (i) (1) trifluoroacetic acid (TFA), DCM, $0{ }^{\circ} \mathrm{C}$ to $\mathrm{rt}$; (2) $\mathbf{1 0}, \mathrm{K}_{2} \mathrm{CO}_{3}, \mathrm{KI}$, $\mathrm{CH}_{3} \mathrm{CN}$, reflux, $\mathrm{N}_{2}$.

\section{The in vitro biological evaluation of target conjugated compounds}

The conjugated compounds $\mathbf{1 1}$ and $\mathbf{1 3}$ were evaluated in the biochemical assay against mTOR and MEK1, as well as the antiproliferative assay against A549 and HCT116 cancer cell lines. Compound 13 exhibited moderately potent inhibitory activity against both mTOR and MEK1 with $\mathrm{IC}_{50}$ values of $0.19 \mu \mathrm{M}$ and $0.98 \mu \mathrm{M}$, respectively. Besides, it demonstrated attractive antiproliferative activity against A549 and HCT116 cell lines with $\mathrm{GI}_{50}$ values of $4.66 \mu \mathrm{M}$ and $5.47 \mu \mathrm{M}$, respectively (Table 1).

Importantly, although its mTOR inhibitory activity and MEK1 inhibitory activity were inferior to MXD-42 and RO5126766, respectively, 13 exerted comparable antiproliferative activity to both reference compounds against the tested two cell lines. This discrepancy between the enzymatic activity and cellular activity indicated that a synergism might be fulfilled by 13 via concurrent inhibition of mTOR and MEK1. The submicromolar bifunctional enzymatic activity and single-digit micromolar cellular potency rendered $\mathbf{1 3}$ as a potential lead for further optimization. When comparing the enzymatic activity of compounds 11 and 13, which share the same mTORbinding fragment and MEK-binding fragment, it became evident that the linker was an important structural factor affecting potency. Thus, in further SAR study, the impact of various chemical linkers on activity would be probed.

\section{Molecular docking}

Molecular docking analysis of $\mathbf{1 3}$ was then conducted to elucidate its possible binding modes with mTOR and MEK1. As illustrated by Fig. 4a, the mTOR-binding fragment of 13 was engaged in $\mathrm{H}$-bond contacts with residues Val2240 in the hinge region and Tyr2225 in the affinity pocket. Meanwhile, the linker tethered to the piperazine moiety, as well as the MEK-binding fragment, was located in a solvent-exposed region. When docked into the allosteric pocket of MEK1 (Fig. 4b), the MEK-binding fragment of $\mathbf{1 3}$ conferred H-bond interactions with residues Val211, Ser212, and Asp208. Similarly, the linker and the mTORbinding fragment extended out of the catalytic cleft. The capability of $\mathbf{1 3}$ to form H-bonds with critical residues in the mTOR and MEK1 catalytic clefts may account for its dual inhibitory activity.

\section{Conclusions and perspectives}

The reciprocal pathway inhibition, along with the enhanced antitumor efficacy, resulted from mTOR inhibitor/MEK inhibitor drug cocktail has provided a fundamental basis for the exploration of polypharmacological agents targeting both mTOR and MEK. Besides the potential to evade the 
Fig. 4 The molecular docking of compound $\mathbf{1 3}$ into the catalytic pocket of mTOR (a) and MEK1 (b) a)

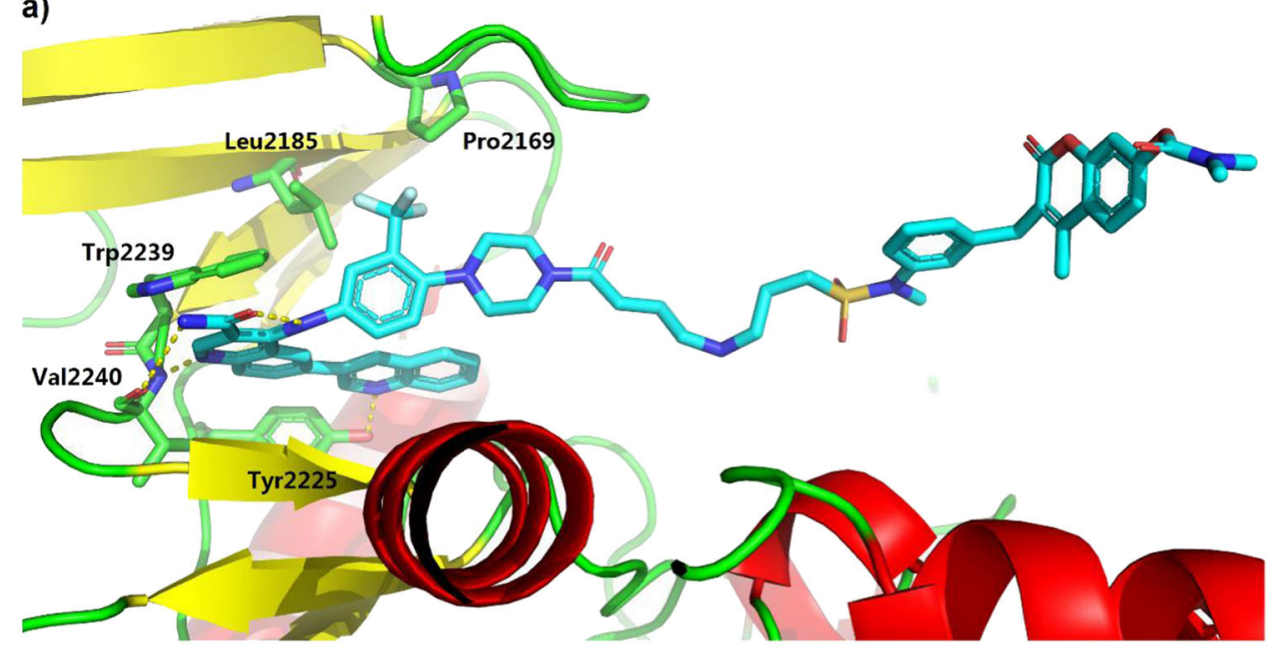

b)

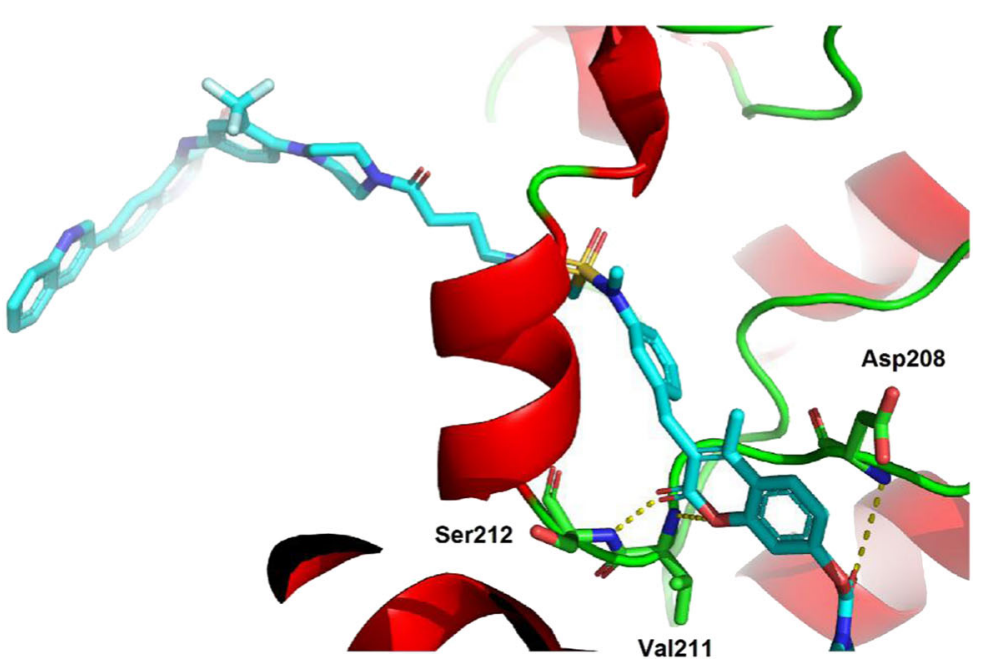

bypass mechanism underlying the resistance to singe pathway inhibition, the bifunctional inhibitors of mTOR and MEK are capable of surmounting the drawbacks of drug cocktails. From this proof-of-principle study, it became evident that the single-agent dual inhibition of mTOR and MEK can be accomplished via covalently attaching mTOR $\mathrm{KI}$ to an allosteric MEK inhibitor. Compound 13, emerging from this strategy, exerted moderately high inhibitory activity against mTOR and MEK1 with $\mathrm{IC}_{50}$ values of $0.19 \mu \mathrm{M}$ and $0.98 \mu \mathrm{M}$, respectively. Particularly, it exhibited comparable antiproliferative activity to both parent compounds against A549 and HCT116 cell lines. To our knowledge, 13 has been the first conjugated mTOR/MEK bifunctional inhibitor reported up to date. However, this prototype dual-targeted inhibitor demands further optimization of the enzyme affinity and the drug-like property. Hence, in the future SAR investigation, MEK-binding fragments generated from more potent allosteric MEK inhibitors will be incorporated, and the chemical diversity of the covalent linkers will be broadened.

\section{Experimental section}

\section{Chemistry}

All the reagents and solvents were purchased from common commercial suppliers. If necessary, purification was carried out prior to use. NMR spectra were recorded on a Bruker Avance 400 II $(400 \mathrm{MHz})$ spectrometer in the indicated solvent. While ESI-MS spectra were obtained by Bruker Esquire-LC-00075 spectrometer, HRMS spectra were recorded on Waters Q-TOF Micromass. Melting points were uncorrected and determined on a WRS-1B melting point apparatus. Flash column chromatography was performed using silica gel (200-300 mesh).

\section{The preparation of ethyl 2-(3-nitrobenzyl)-3-oxobutanoate} (5)

The intermediate was prepared according to a reported protocol (Iikura et al. 2011). To a suspension of $\mathrm{NaH}(60 \%$, 
$1.01 \mathrm{~g}, 25.3 \mathrm{mmol})$ in THF $(30 \mathrm{~mL})$ was added ethyl acetoacetate $(2.9 \mathrm{~mL}, 23.0 \mathrm{mmol})$ at $0{ }^{\circ} \mathrm{C}$, and the resultant mixture was stirred at the same temperature for $0.5 \mathrm{~h}$. Afterwards, the solution of 1-(bromomethyl)-3-nitrobenzene $(5.00 \mathrm{~g}, 23.0 \mathrm{mmol})$ in THF $(20 \mathrm{~mL})$ was added dropwise. The reaction mixture was stirred at room temperature overnight, and quenched with ice water. Following extraction with EA, the organic layer was washed with brine, dried over anhydrous $\mathrm{Na}_{2} \mathrm{SO}_{4}$, and concentrated in vacuo. The crude product was subjected to flash column chromatography $[\mathrm{EA} /$ petroleum ether $(\mathrm{PE})=1: 30]$ to give the title compound as a yellow oil. Yield: $53 \%$.

The preparation of 7-hydroxy-4-methyl-3-(3-nitrobenzyl)$2 \mathrm{H}$-chromen-2-one (6)

The intermediate was prepared according to a reported protocol (Iikura et al. 2011). To a mixture of resorcinol $(0.83 \mathrm{~g}, 7.55 \mathrm{mmol})$ and $5(2.00 \mathrm{~g}, 7.55 \mathrm{mmol})$ was added $\mathrm{H}_{2} \mathrm{SO}_{4}$ (conc., $1.5 \mathrm{~mL}$ ) at $0{ }^{\circ} \mathrm{C}$, and the resultant mixture was stirred at room temperature overnight. After pouring the reaction mixture to ice water, the formed precipitate was filtered off, and washed successively with $\mathrm{H}_{2} \mathrm{O}$ and $\mathrm{MeOH}$ to provide the title intermediate as a slight yellow powder. Yield: $61 \%$. m.p. $216-217^{\circ} \mathrm{C}$.

\section{The preparation of 4-methyl-3-(3-nitrobenzyl)-2-oxo-2H-} chromen-7-yl dimethylcarbamate (7)

To a solution of $6(3.11 \mathrm{~g}, 10.0 \mathrm{mmol})$ in DMF $(20 \mathrm{~mL})$ were added anhydrous $\mathrm{K}_{2} \mathrm{CO}_{3}(1.52 \mathrm{~g}, 11.0 \mathrm{mmol})$ and dimethylcarbamyl chloride $(1.1 \mathrm{~mL}, 12.0 \mathrm{mmol})$. The resultant reaction mixture was stirred at $40{ }^{\circ} \mathrm{C}$ for $4 \mathrm{~h}$, and ice water was added. After collection of the crude product by filtration, flash column chromatography $(\mathrm{EA} / \mathrm{PE}=1: 3)$ was performed to give the title intermediate as a pale solid. Yield: $89 \%$; ${ }^{1} \mathrm{H}$ NMR (400 MHz, DMSO- $\left.d_{6}\right)$ : $\delta 8.15-8.11$ (m, 1H), 8.10-8.05 (m, 1H), 7.87 (d, 8.8 Hz, 1H), 7.72 (d, $7.6 \mathrm{~Hz}, 1 \mathrm{H}), 7.58$ (t, $8.0 \mathrm{~Hz}, 1 \mathrm{H}), 7.26$ (d, $2.4 \mathrm{~Hz}, 1 \mathrm{H}), 7.20$ (dd, 2.4 Hz, $8.8 \mathrm{~Hz}, 1 \mathrm{H}), 4.14$ (s, 2H), 3.07 (s, 3H), 2.94 (s, $3 \mathrm{H}), 2.52(\mathrm{~s}, 3 \mathrm{H})$; ESI-MS: $\mathrm{m} / \mathrm{z}=383[\mathrm{M}+\mathrm{H}]^{+}$; m.p. 192-194 ${ }^{\circ} \mathrm{C}$.

\section{The preparation of 3-(3-aminobenzyl)-4-methyl-2-oxo-2H- chromen-7-yl dimethylcarbamate (8)}

To a solution of $7(1.00 \mathrm{~g}, 2.72 \mathrm{mmol})$ in EA was added $\mathrm{SnCl}_{2}$ (dihydrate) $(3.10 \mathrm{~g}, 13.6 \mathrm{mmol})$, and the resultant mixture was stirred at $50{ }^{\circ} \mathrm{C}$ under $\mathrm{N}_{2}$ atmosphere for $4 \mathrm{~h}$. After adding EA to the mixture, it was quenched with saturated $\mathrm{NaHCO}_{3}$ solution at $0{ }^{\circ} \mathrm{C}$, and washed with water. The organic layer was dried over anhydrous $\mathrm{Na}_{2} \mathrm{SO}_{4}$, and concentrated in vacuo to provide the title intermediate as a pale solid. Yield: 93\%; ${ }^{1} \mathrm{H}$ NMR (400 MHz, DMSO- $\left.d_{6}\right): \delta$ 7.84 (d, $8.8 \mathrm{~Hz}, 1 \mathrm{H}), 7.25$ (d, $2.0 \mathrm{~Hz}, 1 \mathrm{H}), 7.18$ (dd, $2.4 \mathrm{~Hz}$, $8.8 \mathrm{~Hz}, 1 \mathrm{H}), 6.95-6.86(\mathrm{~m}, 1 \mathrm{H}), 6.43-6.33(\mathrm{~m}, 3 \mathrm{H}), 4.96(\mathrm{~s}$, 2H), $3.84(\mathrm{~s}, 2 \mathrm{H}), 3.08(\mathrm{~s}, 3 \mathrm{H}), 2.94(\mathrm{~s}, 3 \mathrm{H}), 2.44(\mathrm{~s}, 3 \mathrm{H})$; ESI-MS: $\mathrm{m} / \mathrm{z}=353[\mathrm{M}+\mathrm{H}]^{+}$; m.p. $155-156^{\circ} \mathrm{C}$.

The preparation of 3-(3-((3-chloropropyl)sulfonamido) benzyl)-4-methyl-2-oxo-2H-chromen-7-yl dimethylcarbamate (9)

To a solution of $\mathbf{8}(1.5 \mathrm{~g}, 4.26 \mathrm{mmol})$ in pyridine $(6 \mathrm{~mL})$ was added 3-chloropropane-1-sulfonyl chloride (0.83 g, $4.69 \mathrm{mmol}$ ), and the resultant reaction mixture was stirred at room temperature for $1 \mathrm{~h}$. Then, the reaction mixture was subjected to flash column chromatography (DCM/EA $=10: 1-8: 1$ ) to give the title intermediate as a pale solid. Yield: $81 \% ;{ }^{1} \mathrm{H}$ NMR (400 MHz, DMSO- $\left.d_{6}\right): \delta 9.79(\mathrm{~s}, 1 \mathrm{H}), 7.85(\mathrm{~d}, 8.8 \mathrm{~Hz}, 1 \mathrm{H})$, $7.29-7.22(\mathrm{~m}, 2 \mathrm{H}), 7.18$ (dd, $2.4 \mathrm{~Hz}, 8.8 \mathrm{~Hz}, 1 \mathrm{H}), 7.12-7.04$ (m, 2H), 6.99 (d, 7.6 Hz, 1H), 3.97 (s, 2H), 3.68 (t, $6.4 \mathrm{~Hz}, 2 \mathrm{H})$, 3.23-3.14 (m, 2H), 3.07 (s, 3H), $2.94(\mathrm{~s}, 3 \mathrm{H}), 2.47(\mathrm{~s}, 3 \mathrm{H})$, 2.12-2.03 (m, 2H); ESI-MS: $\mathrm{m} / \mathrm{z}=493[\mathrm{M}+\mathrm{H}]^{+}$; m.p. $162-165^{\circ} \mathrm{C}$.

The preparation of 3-(3-((3-chloropropyl)- $\mathrm{N}$ methylsulfonamido)benzyl)-4-methyl-2-oxo-2H-chromen-7yl dimethylcarbamate (10)

The intermediate was prepared according to a reported protocol (Van Dort et al. 2015). The mixture of 9 (1.0 g, $2.03 \mathrm{mmol}), \mathrm{MeI}(0.94 \mathrm{~g}, 6.70 \mathrm{mmol}), \mathrm{Cs}_{2} \mathrm{CO}_{3}(1.32 \mathrm{~g}$, $4.06 \mathrm{mmol}$ ), and DMF was stirred at room temperature for $3 \mathrm{~h}$. Afterwards, the reaction mixture was extracted with EA, and washed successively with $\mathrm{H}_{2} \mathrm{O}$ and brine. The organic layer was dried over anhydrous $\mathrm{Na}_{2} \mathrm{SO}_{4}$, and concentrated in vacuo to provide the crude product. Further flash column chromatography $(\mathrm{DCM} / \mathrm{EA}=10: 1)$ gave the title intermediate as a white foam. Yield: $94 \% ;{ }^{1} \mathrm{H}$ NMR (400 MHz, DMSO-d $\left.d_{6}\right): 7.84$ (d, 8.8 Hz, 1H), 7.37-7.23 (m, 4H), 7.22-7.13 (m, 2H), $4.01(\mathrm{~s}, 2 \mathrm{H}), 3.69(\mathrm{t}, 6.4 \mathrm{~Hz}, 2 \mathrm{H})$, 3.28-3.19 (m, 5H), 3.07 (s, 3H), 2.94 (s, 3H), 2.48 (s, 3H), 2.12-2.03 (m, 2H); ESI-MS: $\mathrm{m} / \mathrm{z}=507[\mathrm{M}+\mathrm{H}]^{+}$.

The preparation of 3-(3-)(3-(4-(4-((3'-carbamoyl-[3,6' -biquinolin]-4'-yl)amino)-2-(trifluoromethyl)phenyl) piperazin-1-yl)-propyl)-N-methylsulfonamido)benzyl)-4methyl-2-oxo-2H-chromen-7-yl dimethylcarbamate (11)

The mixture of $\mathbf{1}(145 \mathrm{mg}, 0.25 \mathrm{mmol}), \mathbf{1 0}(106 \mathrm{mg}$, $0.21 \mathrm{mmol}), \mathrm{K}_{2} \mathrm{CO}_{3} \quad(58 \mathrm{mg}, 0.42 \mathrm{mmol}), \mathrm{KI} \quad(70 \mathrm{mg}$, $0.42 \mathrm{mmol})$, TEA $(58 \mu \mathrm{L}, 0.42 \mathrm{mmol})$, and anhydrous $\mathrm{CH}_{3} \mathrm{CN}(2 \mathrm{~mL})$ was refluxed under $\mathrm{N}_{2}$ atmosphere for $12 \mathrm{~h}$. Afterwards, the mixture was concentrated in vacuo, and the residue was directly subjected to flash column 
chromatography $(\mathrm{EA} / \mathrm{MeOH} / \mathrm{TEA}=50: 5: 1-100: 15: 2) \quad$ to give the title compound as a slight yellow hygroscopic solid. Yield: $57 \%$. ${ }^{1} \mathrm{H}$ NMR (400 MHz, DMSO- $d_{6}$ ): 10.49 (brs, 1H), 9.56 (brs, 1H), 9.17-8.78 (m, 2H), $8.62(\mathrm{~s}, 1 \mathrm{H})$, 8.47-7.95 (m, 5H), 7.92-7.60 (m, 4H), 7.59-6.86 (m, 9H), 4.01 (s, 3H), 3.28-2.84 (m, 23H), 2.14-1.94 (m, 2H); ${ }^{13} \mathrm{C}$ NMR $\left(100 \mathrm{MHz}, \mathrm{DMSO}-d_{6}\right): 168.68,160.81,153.25$, $153.24,152.10,149.11,148.16,146.84,146.81,141.36$, $140.13,140.10,133.87,133.20,131.77,129.99\left(\mathrm{q}, J_{\mathrm{C}-\mathrm{F}}=\right.$ $3.8 \mathrm{~Hz}), 129.89$, 129.86, 129.61, 129.15, 128.71, 128.29, $127.41,127.27,126.69,126.59,126.57,126.41,126.34$, $126.29,126.24,125.47,124.86,123.96,123.58\left(\mathrm{q}, J_{\mathrm{C}-\mathrm{F}}=\right.$ $270.0 \mathrm{~Hz}), 122.93,122.85,120.56,119.45,118.38,117.25$, 109.54, 52.07, 45.79, 37.99, 36.32, 36.12, 32.12, 20.72, 15.31, 14.04; ESI-HRMS: $\mathrm{m} / \mathrm{z}$ calcd for $\mathrm{C}_{54} \mathrm{H}_{51} \mathrm{~F}_{3} \mathrm{~N}_{8} \mathrm{O}_{7} \mathrm{~S}$ $[\mathrm{M}+\mathrm{H}]^{+} 1013.3632$, found 1013.3636 ; m.p. $134-137^{\circ} \mathrm{C}$.

The preparation of tert-butyl (4-(4-(4-((3'-carbamoyl-[3,6'biquinolin]-4'-yl)amino)-2-(trifluoromethyl)phenyl) piperazin-1-yl)-4-oxobutyl)carbamate (12)

The solution of 4-((tert-butoxycarbonyl)amino)butanoic acid (212 mg, $1.04 \mathrm{mmol})$, EDCI (301 mg, $1.57 \mathrm{mmol})$ and HOBT (141 mg, $1.04 \mathrm{mmol})$ in DCM (4 mL) was stirred at room temperature for $1 \mathrm{~h}$. Then, $1(301 \mathrm{mg}, 0.52 \mathrm{mmol})$ and TEA $(432 \mu \mathrm{L}, 3.12 \mathrm{mmol})$ were added successively, and the resultant mixture was stirred at room temperature for $4 \mathrm{~h}$. After quenching with saturated $\mathrm{NaHCO}_{3}$ solution at $0{ }^{\circ} \mathrm{C}$, the organic layer was dried over anhydrous $\mathrm{Na}_{2} \mathrm{SO}_{4}$, and concentrated in vacuo. The residue was subjected to flash column chromatography (EA/MeOH/TEA = 150:3:2-150:4:2) to give the title intermediate as a slight yellow solid. Yield: 70\%; ${ }^{1} \mathrm{H}$ NMR (400 MHz, DMSO- $d_{6}$ ): 10.31 (s, 1H), 9.05 $(\mathrm{d}, 2.0 \mathrm{~Hz}, 1 \mathrm{H}), 8.96(\mathrm{~s}, 1 \mathrm{H}), 8.58(\mathrm{~d}, 1.6 \mathrm{~Hz}, 1 \mathrm{H}), 8.34$ (d, $1.6 \mathrm{~Hz}, 1 \mathrm{H}), 8.29$ (dd, $2.0 \mathrm{~Hz}, 8.8 \mathrm{~Hz}, 1 \mathrm{H}), 8.17$ (brs, 1H), $8.13(\mathrm{~d}, 8.4 \mathrm{~Hz}, 1 \mathrm{H}), 8.07$ (d, $8.4 \mathrm{~Hz}, 1 \mathrm{H}), 8.02$ (d, $8.0 \mathrm{~Hz}$, 1H), 7.84-7.77 (m, 1H), 7.72-7.60 (m, 2H), $7.51(\mathrm{~d}, 8.8 \mathrm{~Hz}$, $1 \mathrm{H}), 7.41(\mathrm{~d}, 2.4 \mathrm{~Hz}, 1 \mathrm{H}), 7.30(\mathrm{dd}, 2.0 \mathrm{~Hz}, 8.4 \mathrm{~Hz}, 1 \mathrm{H})$, $6.83(\mathrm{t}, 4.8 \mathrm{~Hz}, 1 \mathrm{H}), 3.65-3.46(\mathrm{~m}, 4 \mathrm{H}), 3.02-2.92(\mathrm{~m}, 2 \mathrm{H})$, 2.90-2.75 (m, 4H), 2.34 (t, 7.2 Hz, 1H), 1.71-1.57 (m, 2H), 1.38 (s, 9H); ESI-MS: $\mathrm{m} / \mathrm{z}=728[\mathrm{M}+\mathrm{H}]^{+} ; \quad$ m.p. $131-135^{\circ} \mathrm{C}$.

\section{The preparation of 3-(3-)(3-((4)-(4-(4-)((3'-carbamoyl-[3,6'- biquinolin]-4'-yl)amino)-2-(trifluoromethyl)phenyl) piperazin-1-yl)-4-oxobutyl)amino)-propyl)- $\mathrm{N}$ - methylsulfonamido)benzyl)-4-methyl-2-oxo-2H-chromen-7- yl dimethylcarbamate (13)}

The intermediate 12 was dissolved in DCM (4 mL), and to the solution was added TFA $(1 \mathrm{~mL})$ dropwise at $0{ }^{\circ} \mathrm{C}$. Subsequently, the resultant mixture was stirred at room temperature for $4 \mathrm{~h}$. After concentrating the mixture in vacuo, the Boc-deprotected product was afforded as a slight yellow foam, which was directly used for the next reaction without further purification. ESI-MS: $\mathrm{m} / \mathrm{z}=628[\mathrm{M}+\mathrm{H}]^{+}$.

The mixture of $\mathbf{1 0}(0.095 \mathrm{~g}, 0.19 \mathrm{mmol})$, the Bocdeprotected product $(0.24 \mathrm{~g}, 0.38 \mathrm{mmol}$, calculated as the pure product), $\mathrm{K}_{2} \mathrm{CO}_{3}(0.052 \mathrm{~g}, 0.38 \mathrm{mmol}), \mathrm{KI}(0.063 \mathrm{~g}$, $0.38 \mathrm{mmol})$, and anhydrous $\mathrm{CH}_{3} \mathrm{CN}(2 \mathrm{~mL})$ was refluxed under $\mathrm{N}_{2}$ atmosphere for $8 \mathrm{~h}$. Then, the mixture was concentrated in vacuo, and DCM/MeOH $(1: 1, V: V)$ was added to the residue. After filtration, the filtrate was concentrated in vacuo. The residue was subjected to flash column chromatography $(\mathrm{EA} / \mathrm{MeOH} / \mathrm{TEA}=50: 5: 1-100: 15: 2)$ to give 13 as a slight yellow hygroscopic solid. Yield: $62 \%$ (for two steps). ${ }^{1} \mathrm{H}$ NMR (400 MHz, DMSO- $d_{6}$ ): 10.34 (s, 1H), 9.04 $(\mathrm{s}, 1 \mathrm{H}), 8.97(\mathrm{~s}, 1 \mathrm{H}), 8.65-8.52(\mathrm{~m}, 1 \mathrm{H}), 8.35(\mathrm{~s}, 1 \mathrm{H}), 8.28$ $(\mathrm{d}, 8.8 \mathrm{~Hz}, 1 \mathrm{H}), 8.19(\mathrm{~s}, 1 \mathrm{H}), 8.12(\mathrm{~d}, 8.8 \mathrm{~Hz}, 1 \mathrm{H}), 8.05(\mathrm{~d}$, $8.4 \mathrm{~Hz}, 1 \mathrm{H}), 8.00(\mathrm{~d}, 8.0 \mathrm{~Hz}, 1 \mathrm{H}), 7.87-7.75(\mathrm{~m}, 2 \mathrm{H})$, $7.72-7.59(\mathrm{~m}, 2 \mathrm{H}), 7.49(\mathrm{~d}, 8.4 \mathrm{~Hz}, 1 \mathrm{H}), 7.42(\mathrm{~s}, 1 \mathrm{H})$, 7.37-7.22 (m, 4H), 7.21-7.09 (m, 2H), 4.06-3.92 (m, 2H), 3.63-3.50 (m, 4H), 3.28-3.18 (m, 7H), $3.05(\mathrm{~s}, 3 \mathrm{H}), 2.92(\mathrm{~s}$, $3 \mathrm{H}), 2.88-2.75(\mathrm{~m}, 6 \mathrm{H}), 2.49-2.42(\mathrm{~m}, 5 \mathrm{H}), 2.03-1.90(\mathrm{~m}$, $2 \mathrm{H}), 1.85-1.73(\mathrm{~m}, 2 \mathrm{H}) ;{ }^{13} \mathrm{C}$ NMR $\left(100 \mathrm{MHz}, \mathrm{DMSO}-d_{6}\right)$ : $170.06,168.99,160.82,153.27,153.23,152.11,150.56$, $149.19,149.09,148.18,146.82,146.78,146.22,141.41$, $140.77,140.04,133.61,133.10,131.94,130.48,129.80$, $129.50,129.11,128.73,128.25,127.44,127.22,126.69$, $126.47, \quad 126.43 \quad\left(\mathrm{q}, \quad J_{\mathrm{C}-\mathrm{F}}=270.2 \mathrm{~Hz}\right), \quad 126.38, \quad 126.23$, $125.69,124.37,123.93,122.94,122.87,120.75,118.40$, $118.18\left(\mathrm{q}, J_{\mathrm{C}-\mathrm{F}}=5.8 \mathrm{~Hz}\right), 117.26,114.53,109.57,53.42$, 53.01, 47.03, 46.00, 45.66, 45.39, 41.60, 37.96, 36.33, 36.13, 32.08, 29.55, 22.29, 20.84, 15.31; ESI-HRMS: m/z calcd for $\mathrm{C}_{58} \mathrm{H}_{58} \mathrm{~F}_{3} \mathrm{~N}_{9} \mathrm{O}_{8} \mathrm{~S}[\mathrm{M}+\mathrm{H}]^{+}$1098.4159, found 1098.4156; m.p. $147-148^{\circ} \mathrm{C}$.

\section{Biology}

\section{In vitro enzymatic assay}

The Lance Ultra assay and Mobility Shift assay were performed to identify the mTOR inhibitory activity and MEK1 inhibitory activity, respectively.

In the Lance Ultra assay, the compound solutions were prepared at fourfold of the final concentrations via serial dilution with DMSO and the subsequent dilution with the kinase buffer. The kinase solution was prepared with the kinase buffer at fourfold of the final concentration. The substrate solution containing ULight-4E-BP1 peptide (Thr37/46, PE) and ATP was prepared with the kinase buffer at twofold of the final concentration. The kinase reaction mixture in each well was composed of $2.5 \mu \mathrm{L}$ of compound solution, $2.5 \mu \mathrm{L}$ of kinase solution, and $5 \mu \mathrm{L}$ of substrate solution. After being incubated at room temperature for $0.5 \mathrm{~h}, 10 \mu \mathrm{L}$ of kinase detection buffer containing EDTA 
and Eu-anti-phospho-4E-BP1 antibody (Thr37/46, PE) was added to each well of the assay plate. Before reading on Envision, the mixture need be mixed briefly with centrifuge and was allowed to equilibrate for $1 \mathrm{~h}$. After calculating the percent inhibition from lance signal, the curves were fitted with four-parameter logistic model in XLFit to give $\mathrm{IC}_{50}$ values.

In the Mobility Shift assay, the compound solutions were prepared at fivefold of the final concentrations via serial dilution with DMSO and the subsequent dilution with the kinase buffer. Both the kinase solution and the peptide solution containing FAM-labeled peptide and ATP were prepared with the kinase buffer at 2.5 -fold of the final concentration. The kinase reaction mixture in each well was composed of $5 \mu \mathrm{L}$ of compound solution, $10 \mu \mathrm{L}$ of kinase solution, and $10 \mu \mathrm{L}$ of substrate solution. $25 \mu \mathrm{L}$ of stop buffer $[2 \times, 100 \mathrm{mM}$ HEPES ( $\mathrm{pH}=7.5$ ), $0.015 \%$ Brij-35, $0.2 \%$ coating reagent, $50 \mathrm{mM}$ EDTA] was added to quench the kinase reaction. After the data collection on Caliper, the percent inhibition was calculated, and the curves were fitted with fourparameter logistic model in XLFit to give $\mathrm{IC}_{50}$ values.

\section{Antiproliferative assay}

The antiproliferative activity of compounds was evaluated via the Cell Counting Kit-8 (CCK-8) assay. The cells were seeded into 96 -well plate. After being cultured overnight $\left(5 \% \mathrm{CO}_{2}, 37{ }^{\circ} \mathrm{C}\right)$, cells in 96 -well plates were subjected to exposure to serially diluted compound solutions. Culture medium was discarded, and a mixture of fresh culture medium and CCK-8 (9:1, V:V) was added. Cells were cultured for $4 \mathrm{~h}$, and the percent inhibition was calculated from the OD value measured at $570 \mathrm{~nm}$ with a multiscan spectrum. The curves were fitted with $\log$ (inhibitor) vs. response-variable slope in Graphpad Prism 5 to give $\mathrm{GI}_{50}$ values.

\section{Molecular docking}

The co-crystal structure of mTOR in complex with Torin 2 (Yang et al. 2013) (PDB code 4JSX) and that of MEK1 in complex with RO-5126766 (PDB code 3WIG) were used for the docking calculation in C-DOCKER module of Discovery Studio (Version 2.1). For preparing the ligands, 3D structures were generated and their energy minimization performed. For preparing the receptors, the hydrogen atoms were added and the CHARMm-force field employed. The site sphere was determined based on the binding location of Torin 2 in mTOR or RO-5126766 in MEK1. Torin 2 was removed, and compound $\mathbf{1 3}$ was docked into the defined site in mTOR. Similarly, RO-5126766 was removed, and compound $\mathbf{1 3}$ was docked into the defined site in MEK1. After analyzing the types of interactions between $\mathbf{1 3}$ and
mTOR or MEK1, the final binding conformation in mTOR or MEK was determined according to the calculated energy.

Acknowledgements The authors acknowledge the financial support of the Natural Science Foundation of Anhui Province (1808085QH261), the Key Project of Natural Science Research in Universities of Anhui Province (KJ2019A1004), and University-Enterprise Cooperative Projects (2018HZ6 and 2019HZ078).

\section{Compliance with ethical standards}

Conflict of interest The authors declare that they have no conflict of interest.

Publisher's note Springer Nature remains neutral with regard to jurisdictional claims in published maps and institutional affiliations.

\section{References}

Cante-Barrett K, Spijkers-Hagelstein JA, Buijs-Gladdines JG, Uitdehaag JC, Smits WK, van der Zwet J, Buijsman RC, Zaman GJ, Pieters R, Meijerink JP (2016) MEK and PI3K-AKT inhibitors synergistically block activated IL7 receptor signaling in T-cell acute lymphoblastic leukemia. Leukemia 30(9):1832-1843

Chappell WH, Steelman LS, Long JM, Kempf RC, Abrams SL, Franklin RA, Basecke J, Stivala F, Donia M, Fagone P, Malaponte G, Mazzarino MC, Nicoletti F, Libra M, MaksimovicIvanic D, Mijatovic S, Montalto G, Cervello M, Laidler P, Milella M, Tafuri A, Bonati A, Evangelisti C, Cocco L, Martelli AM, McCubrey JA (2011) Ras/Raf/MEK/ERK and PI3K/PTEN/Akt/ mTOR inhibitors: rationale and importance to inhibiting these pathways in human health. Oncotarget 2(3):135-164

Chow JY, Quach KT, Cabrera BL, Cabral JA, Beck SE, Carethers JM (2017) RAS/ERK modulates TGFbeta-regulated PTEN expression in human pancreatic adenocarcinoma cells. Carcinogenesis 28(11):2321-2327

Van Dort ME, Galban S, Nino CA, Hong H, Apfelbaum AA, Luker GD, Thurber GM, Atangcho L, Besirli CG, Ross BD (2017) Structure-guided design and initial studies of a bifunctional MEK/PI3K inhibitor (ST-168). ACS Med Chem Lett 8:808-813

Van Dort ME, Galban S, Wang H, Sebolt-Leopold J, Whitehead C, Hong H, Rehemtulla A, Ross BD (2015) Dual inhibition of allosteric mitogen-activated protein kinase (MEK) and phosphatidylinositol 3-kinase (PI3K) oncogenic targets with a bifunctional inhibitor. Bioorg Med Chem 23(24):1386-1394

Eser S, Reiff N, Messer M, Seidler B, Gottschalk K, Dobler M, Hieber M, Arbeiter A, Klein S, Kong B, Michalski CW, Schlitter AM, Esposito I, Kind AJ, Rad L, Schnieke AE, Baccarini M, Alessi DR, Rad R, Schmid RM, Schneider G, Saur D (2013) Selective requirement of PI3K/PDK1 signaling for Kras oncogene-driven pancreatic cell plasticity and cancer. Cancer Cell 23(3):406-420

Garcia-Garcia C, Rivas MA, Ibrahim YH, Calvo MT, Gris-Oliver A, Rodriguez O, Grueso J, Anton P, Guzman M, Aura C, Nuciforo P, Jessen K, Argiles G, Dienstmann R, Bertotti A, Trusolino L, Matito J, Vivancos A, Chicote I, Palmer HG, Tabernero J, Scaltriti M, Baselga J, Serra V (2015) MEK plus PI3K/mTORC1/ 2 therapeutic efficacy is impacted by TP53 mutation in preclinical models of colorectal cancer. Clin Cancer Res 21(24):5499-5510

Heavey S, Cuffe S, Finn S, Young V, Ryan R, Nicholson S, Leonard N, McVeigh N, Barr M, O'Byrne K, Gately K (2016) In pursuit of synergy: an investigation of the PI3K/mTOR/MEK co-targeted inhibition strategy in NSCLC. Oncotarget 7(48):79526-79543 
Holt SV, Logie A, Davies BR, Alferez D, Runswick S, Fenton S, Chresta CM, Gu Y, Zhang J, Wu YL, Wilkinson RW, Guichard SM, Smith PD (2012) Enhanced apoptosis and tumor growth suppression elicited by combination of MEK (selumetinib) and mTOR kinase inhibitors (AZD8055). Cancer Res 72(7):1804-1813

Iikura H, Hyoudoh I, Aoki T, Furuichi N, Matsushita M, Watanabe F, Ozawa S, Sakaitani M, Ho PS, Tomii Y, Takanashi K, Harada N (2011) Coumarin derivative having antitumor activity US 8278465:B2

Lito P, Saborowski A, Yue J, Solomon M, Joseph E, Gadal S, Saborowski M, Kastenhuber E, Fellmann C, Ohara K, Morikami K, Miura T, Lukacs C, Ishii N, Lowe S, Rosen N (2014) Disruption of CRAF-mediated MEK activation is required for effective MEK inhibition in KRAS mutant tumors. Cancer Cell 25(5):697-710

Ma XD, Lv XQ, Qiu N, Yang B, He QJ, Hu YZ (2015) Discovery of novel quinoline-based $\mathrm{mTOR}$ inhibitors via introducing intramolecular hydrogen bonding scaffold (iMHBS): the design, synthesis and biological evaluation. Bioorg Med Chem 23 (24):7585-7596

Ma XD, Lv XQ, Zhang JK (2018) Exploiting polypharmacology for improving therapeutic outcome of kinase inhibitors (KIs): an update of recent medicinal chemistry efforts. Eur J Med Chem 143:449-463

Mohan S, Vander Broek R, Shah S, Eytan DF, Pierce ML, Carlson SG, Coupar JF, Zhang J, Cheng H, Chen Z, Van Waes C (2015) MEK inhibitor PD-0325901 overcomes resistance to PI3K/mTOR inhibitor PF-5212384 and potentiates antitumor effects in human head and neck squamous cell carcinoma. Clin Cancer Res 21 (17):3946-3956
Park H, Kim Y, Sul JW, Jeong IG, Yi HJ, Ahn JB, Kang JS, Yun J, Hwang JJ, Kim CS (2015) Synergistic anticancer efficacy of MEK inhibition and dual PI3K/mTOR inhibition in castrationresistant prostate cancer. Prostate 75(15):1747-1759

Pitts TM, Newton TP, Bradshaw-Pierce EL, Addison R, Arcaroli JJ, Klauck PJ, Bagby SM, Hyatt SL, Purkey A, Tentler JJ, Tan AC, Messersmith WA, Eckhardt SG, Leong S (2014) Dual pharmacological targeting of the MAP kinase and $\mathrm{PI} 3 \mathrm{~K} / \mathrm{mTOR}$ pathway in preclinical models of colorectal cancer. PLoS ONE 9(11): e113037

Renshaw J, Taylor KR, Bishop R, Valenti M, De Haven Brandon A, Gowan S, Eccles SA, Ruddle RR, Johnson LD, Raynaud FI, Selfe JL, Thway K, Pietsch T, Pearson AD, Shipley J (2013) Dual blockade of the PI3K/AKT/mTOR (AZD8055) and RAS/MEK/ ERK (AZD6244) pathways synergistically inhibits rhabdomyosarcoma cell growth in vitro and in vivo. Clin Cancer Res 19 (21):5940-5951

Tsai CJ, Nussinov R (2013) The molecular basis of targeting protein kinases in cancer therapeutics. Semin Cancer Biol 23 (4):235-242

Yang H, Rudge DG, Koos JD, Vaidialingam B, Yang HJ, Pavletich NP (2013) mTOR kinase structure, mechanism and regulation. Nature 497(7448):217-223

Yang HW, Shin MG, Lee S, Kim JR, Park WS, Cho KH, Meyer T, Heo WD (2012) Cooperative activation of PI3K by Ras and Rho family small GTPases. Mol Cell 47(2):281-290

Zhang JS, Koenig A, Harrison A, Ugolkov AV, Fernandez-Zapico ME, Couch FJ, Billadeau DD (2011) Mutant K-Ras increases GSK-3beta gene expression via an ETS-p300 transcriptional complex in pancreatic cancer. Oncogene 30(34):3705-3715 